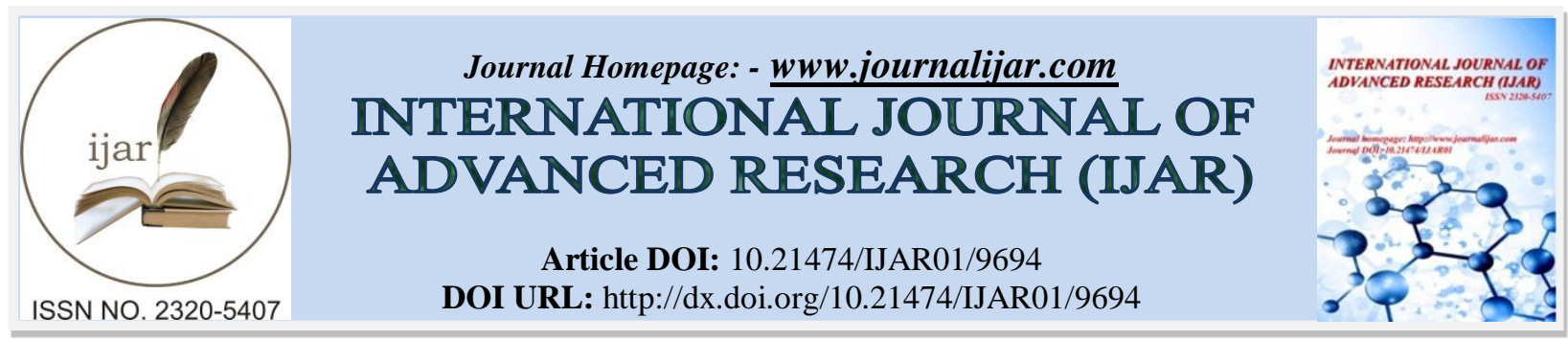

RESEARCH ARTICLE

\title{
COMPARATIVE EFFECTS OF BREWERY WASTE-BASED COMPOSTS ON SOME SOIL CHEMICAL PROPERTIES AND YIELD OF AMARANTHUS CAUDATUS.
}

Ebido N. E. ${ }^{1}$ and Ndubuaku U. $M^{2}$.

1. Department of Soil Science, University of Nigeria, Nsukka.

2. Department of Crop Science, University of Nigeria, Nsukka.

\section{Manuscript Info}

Manuscript History

Received: 08 July 2019

Final Accepted: 10 August 2019

Published: September 2019

Key words:-

Brewery waste (spent grains), Compost, Soil nutrient status, Soil amendment.

\begin{abstract}
Composting of brewery waste (spent grains) into organic fertilizers can serve the multipurpose of conversion of waste to useful material, reduction of air and soil pollution as well as the cost of waste disposal. The research was aimed at determining the effects of brewery wastebased composts on some physical and chemical properties of the soil and the yield of Amaranth (Amaranthus caudatus). The experiment was conducted at the Organic Vegetable Garden for Teaching and Research, Department of Agronomy, University of Ibadan, Ibadan. Treatments used were $20 \mathrm{t} / \mathrm{ha}$ of spent grain (SG) + Poultry dropping (PD) (1:1 and $2: 1 ; \mathrm{v} / \mathrm{v})$, spent grain $(\mathrm{SG})+$ cow dung $(\mathrm{CD})(1: 1$ and $2: 1 ; \mathrm{v} / \mathrm{v})$, spent grain (SG) alone (100\% SG) and control (un-amended soil). The experiment was laid out in a randomized complete block design (RCBD) with four replications. The data collected were subjected to analysis of variance and means separated using Fisher's least significant difference (LSD). The spent grains plus poultry droppings performed better than the spent grains plus cow dung in the release of organic matter, $\mathrm{P}, \mathrm{N}, \mathrm{K}, \mathrm{Na}$ and $\mathrm{Ca}$ into the soil after the first and residual planting. All the treatments reduced the exchangeable acidity when compared with the control. Soils treated with spent grains plus poultry droppings (1:1) gave the highest values of organic carbon of 33.0 and $31.0 \mathrm{~g} / \mathrm{kg}$ ) and nitrogen of 2.98 and $2.91 \mathrm{~g} / \mathrm{kg}$ respectively after the main and residual trials. The highest yield values were obtained in the spent grains plus poultry droppings (1:1) and the least in the control (un-amended) in both in both first (treatment) and second (residual) planting. In conclusion, the use of brewery waste-based composts for soil amendment added value to the improvement of the soil nutrient status.
\end{abstract}

Copy Right, IJAR, 2019,. All rights reserved.

\section{Introduction:-}

One major problem facing agriculture in Nigeria today is that the fertility status of most Nigerian soils are generally low (FAO, 2001). Therefore, the problem is how to improve the fertility and hence the productivity of the soil for increased agricultural production (Azagaku and Anzaku, 2002). Many tropical soils are poor in nutrients and rely on the recycling of nutrients from soil organic matter to maintain adequate fertility level. Thus, quantification of

Corresponding Author:-Ebido N. E..

Address:-Department of Soil Science, University of Nigeria, Nsukka. 
organic matter cycling is an important guide to the agricultural potential of tropical soils (Tiessen et al., 1994). The status of soil fertility in the tropics is of considerable importance in food security due to increase in global population growth and major portion of this growth occurs in the tropics. Soil fertility mainly depends on its nutrient status, the amount and rate of nutrients supplied for plant growth. Sufficient nutrient supply is an essential factor in plant growth. With sufficient supply of nutrients in the soil, plants are likely to grow well and produce high yield. Soil amendments in the form of mineral fertilizer or organic manure improve soil productivity and ultimate crop yield.

Organic fertilizers are properly decomposed residual matter into non humic substances (Davison et al., 2000). These organic fertilizers could be associated with limitations such as; scarcity, slow nutrient release and high cost of transportation (Somani and Totawat, 1996). Therefore, any method that will aid better release of nutrient and reduce bulkiness resulting to optimum crop yield is essential in the use of organic manure (Ande et al., 2010). Organic fertilizers also have long term residual effects due to their slow decomposition and mineralization rate, which maintain soil fertility in continuous cropping (Seran et al., 2010).

Compost is an organic matter source, it is the decomposed remnants of organic materials. Finished compost generally varies from dark brown to black in colour and has a pleasant earthy odour. The $\mathrm{pH}$ is close to neutral. A compost has a unique ability to improve the chemical, physical, and biological characteristics of soils (Getinet, 2016; Amlinger et al., 2007). It enhances water retention in sandy soils and structure of clayey soils by increasing the soil aggregates stability (Brown and Cotton, 2011). Addition of compost improves the soil fertility and cation exchange capacity (Agegnehu et al., 4014; Mohammad et al., 2004) thereby reducing fertilizer requirements to about 50\% (Ndubuaku and Lucas, 2000). The proportion of humus increases and the carbon to nitrogen (C:N) ratio decreases. Soil becomes microbially-active (Amlinger et al., 2007; Brown and Cotton, 2011; Paul, 2003). This enhanced microbial activity also accelerates the breakdown of pesticides and other synthetic organic compounds (Maki et al., 2005). Compost amendments reduce the bioavailability of heavy metals (Paradelo et al., 2011) which is an important quality in the remediation of contaminated soils. Compost provides large quantities of organic matter and nutrients (such as nitrogen and potassium) to the soil making compost a good organic fertilizer (U. S. EPA, 2002).

To improve the fertility status of the soil over a long term, there is a need to use organic fertilizers such as compost. Brewery waste which has been utilised for agricultural purposes should be utilised in composting with other agricultural waste. However, much work has not been done on examining the influence of composted brewery waste with animal wastes like poultry manure and cow dung on soil nutrients. The objective of this study was to determine the effects of brewery waste-based composts on some physical and chemical properties of the soil as well as yield of Amaranthus caudatus.

\section{Materials And Methods:-}

The experiments were conducted at the Organic Vegetable Garden for Teaching and Research and Soil Science Laboratory, Department of Agronomy, Faculty of Agriculture and Fisheries, University of Ibadan, Ibadan.

Field experiment to determine the effects of brewery waste based compost on soil nutrient status was carried out. The experiment was conducted on a previously-used arable farm land. Spent grain (SG) + Poultry dropping (PD), spent grain (SG) + cow dung (CD) and spent grain (SG) alone were composted in three different ratios (1:1, 2:1 and 3:1). $20 \mathrm{t} / \mathrm{ha}$ each of the composted SG + PD (1:1), SG + PD (2:1), SG + CD (1:1), SG + CD (2:1), and SG (100\%) were used for the experiment. The lay-out of experiment was randomized complete block design (RCBD) with four replications. The plot size was $7.5 \mathrm{~m}$ x $8.5 \mathrm{~m}$ with twenty four beds. Each bed was $1.5 \mathrm{~m} \mathrm{x} 1.0 \mathrm{~m} \mathrm{spaced} 50 \mathrm{~cm}$ apart. Amaranthus caudatus seeds were sowed in drills $(50 \mathrm{~cm}$ apart) and harvested 4 weeks after planting. Weeds were controlled by hand picking. Plots were irrigated before planting and subsequent routine irrigation was done every other day until harvest. After harvesting, the plot was cleared manually for residual planting. Seeds were sowed in drills and harvested 4 weeks after the second planting.

Auger soil samples were collected separately from each bed after each (first and second) harvest. The soil samples were air-dried and taken to the laboratory for physical and chemical analyses. The air-dried soil samples were crushed gently with pestle and mortar, sieved using $2 \mathrm{~mm}$ mesh-sized sieve to remove coarse particles. The soil samples were subjected to routine analysis. The physical property analysed included; Particle size distribution (sand, silt and clay) using the hydrometer method (Bouyoucos, 1962). Chemical properties included soil pH, organic 
carbon which was converted to organic matter by multiplying with the factor of 1.724 , cation exchange capacity (C.E.C), Total N, exchangeable cations (Ca, $\mathrm{Mg}, \mathrm{K}$ and $\mathrm{Na}$ ) and available Phosphorus.

\section{Analysis of the Chemical Properties}

The $\mathrm{pH}\left(\mathrm{H}_{2} \mathrm{O}\right.$ 1:1) of the soil samples was determined using the $\mathrm{pH}$ meter. Phosphorus was determined by the Bray II method using colorimetric assessment according to AOAC (2005). The determination of C.E.C and exchangeable cations were done by using the Ammonium acetate method. The organic carbon content was determined by wet dichromate acid oxidation method (Nelson and Sommers, 1982). The organic matter was gotten by multiplying the $\%$ carbon by $1.724(1.0 \% \mathrm{O} . \mathrm{M}=\% \mathrm{C} \times 1.724)$. The total nitrogen of the soil was determined using the kjedahl apparatus (Bremner and Mulvaney, 1982). The exchangeable bases were determined by using Atomic Absorption spectrophotometer (AAS).

Statistical analysis was done using SAS. Least significant difference at 5\% probability, means and the standard deviation on the chemical properties were determined.

\section{Results:-}

\section{Physical and chemical properties of the soil before planting}

The result in Table 1 indicates the physical and chemical properties of the soil before application of soil amendment (brewery waste-based compost).

The textural class of the soil is sandy soil with slightly acidic $\mathrm{pH}$ of 6.5 , high amount of exchangeable acidity of 1.1 $\mathrm{cmol} / \mathrm{kg}$, total organic carbon, nitrogen and calcium of $19.7 \mathrm{~g} / \mathrm{kg}, 2.41 \mathrm{~g} / \mathrm{kg}$ and $1.9 \mathrm{cmol} / \mathrm{kg}$ respectively. The total phosphorus level was very high $(23 \mathrm{mg} / \mathrm{kg})$. The potassium was very low $(0.1 \mathrm{cmol} / \mathrm{kg})$ with low amount of sodium $(0.1 \mathrm{cmol} / \mathrm{kg})$.

\section{Effects of organic fertilizer on the yield of amaranth after first (treatment application) and second (residual) planting}

All the amended soils with the compost manure gave higher yields than the control (un-amended soil) as shown in Table 2. The highest yield values were obtained in the spent grains plus poultry droppings (1:1) and the least yield was obtained in the control (un-amended) in both in both first (treatment) and second (residual) planting. Spent grain plus poultry droppings (1:1) was significantly different from other treatments and control. However, higher yields were obtained in the first planting than the second planting.

Effects of organic fertilizer on some chemical properties of the soil after first (treatment application) planting The result presented in Table 3 showed that the treatments reduced the exchangeable acidity and increased the total organic carbon and cation exchange capacity when compared to the control. The experiment showed that the $\mathrm{pH}$ of all the treatments was slightly acidic which ranged from 6.5 for the untreated soil (control) to 6.7 and 6.8 for treated soils. The compost treatments slightly increased the amount of organic carbon, total nitrogen and available phosphorus in the soil. The soil organic carbon content of the untreated soil (control) was high $(20.1 \mathrm{~g} / \mathrm{kg}$ ) and those of the treated soils were very high and ranged from $26.1 \mathrm{~g} / \mathrm{kg}(\mathrm{SG}+\mathrm{CD} 1: 1)$ to $31.0 \mathrm{~g} / \mathrm{kg}$ (SG + PD 1:1). The total nitrogen content of the untreated soil (control) was moderately high $(2.41 \mathrm{~g} / \mathrm{kg}$ ) and those of the treated soils very high and ranged from $2.50 \mathrm{~g} / \mathrm{kg}$ ( $\mathrm{SG}+\mathrm{CD} 1: 1)$ to $2.98 \mathrm{~g} / \mathrm{kg}$ (SG + PD 1:1). The available P value of the untreated soil (control) was also high $(25.39 \mathrm{mg} / \mathrm{kg}$ ) and those of the treated soils were very high and ranged from 39.62 (SG + CD 2:1) to 57.61 (SG + PD 2:1). Generally, the treatments increased the O.C, available P, N, K, Na, Ca, Mg and CEC (Table 3).

\section{Effects of organic fertilizer on some chemical properties of the soil after second (residual) planting}

The residual effects of the treatments showed a reduction in the exchangeable acidity and increase in the total organic carbon and cation exchange capacity when compared to the control. The result showed that the $\mathrm{pH}$ of all the treatments was slightly acidic and ranged from 6.3 for the untreated soil (control) to 6.4 and 6.5 for treated soils. The compost treatments slightly increased the amount of organic carbon, total nitrogen and available phosphorus in the soil. The soil organic carbon content of the untreated soil (control) was high $(19.7 \mathrm{~g} / \mathrm{kg}$ ) and those of the treated soils were very high and ranged from $24.1 \mathrm{~g} / \mathrm{kg}$ ( $\mathrm{SG}+\mathrm{CD} 1: 1)$ to $33.0 \mathrm{~g} / \mathrm{kg}$ (SG + PD 1:1). The total nitrogen of the untreated soil (control) was moderately high $(2.36 \mathrm{~g} / \mathrm{kg})$ while those of the treated soils were very high and ranged from $2.47 \mathrm{~g} / \mathrm{kg}$ (SG + CD 1:1) to $2.91 \mathrm{~g} / \mathrm{kg}$ (SG + PD 1:1). The available P value of the untreated soil (control) was also high $(24.75 \mathrm{mg} / \mathrm{kg}$ ) and those of the treated soils were very high and ranged from $33.58 \mathrm{mg} / \mathrm{kg}$ (SG $100 \%)$ to 
$45.27 \mathrm{mg} / \mathrm{kg}$ (SG + PD 2:1). Generally, all the treatments increased the O.C, available P, N, K, Na, Ca, Mg and CEC of the soil in the residual planting (Table 4).

Table 1:-Soil physical and chemical properties before treatment application

\begin{tabular}{|l|l|}
\hline Physical/chemical properties & Value \\
\hline $\mathrm{pH}\left(\mathrm{H}_{2} \mathrm{O} 1: 1\right)$ & 6.5 \\
\hline Organic Carbon $(\mathrm{g} / \mathrm{kg})$ & 19.7 \\
\hline Avail $\mathrm{P}(\mathrm{mg} / \mathrm{kg})$ & 23 \\
\hline Total $\mathrm{N}(\mathrm{g} / \mathrm{kg})$ & 2.4 \\
\hline Exchangeable bases $(\mathrm{cmol} / \mathrm{kg})$ & \\
\hline $\mathrm{Ca}$ & 1.9 \\
\hline $\mathrm{Mg}$ & 0.4 \\
\hline $\mathrm{K}$ & 0.1 \\
\hline $\mathrm{Na}$ & 0.1 \\
\hline Exchangeable Acidity $(\mathrm{cmol} / \mathrm{kg})$ & 1.1 \\
\hline Ex $\mathrm{H}^{+}$ & 0.4 \\
\hline Ex A ${ }^{3+}$ & 0.7 \\
\hline Micro Nutrients $(\mathrm{mg} / \mathrm{kg})$ & \\
\hline $\mathrm{Mn}$ & 20 \\
\hline Fe & 236 \\
\hline $\mathrm{Cu}$ & 5 \\
\hline Zn & 1 \\
\hline Particle size distribution $(\mathrm{g} / \mathrm{kg})$ & \\
\hline Clay & 48 \\
\hline Silt & 94 \\
\hline Sand & 878 \\
\hline Textural class & Sandy soil \\
\hline
\end{tabular}

Table 2:-Effects of organic fertilizer on plant yield after treatment and residual planting

\begin{tabular}{|l|l|l|}
\hline Treatments & First (Treatment) t/ha & Second (Residual) t/ha \\
\hline SG + PD (1:1) & $46.01 \mathrm{a}$ & $38.12 \mathrm{a}$ \\
\hline SG + PD (2:1) & $36.45 \mathrm{ab}$ & $15.52 \mathrm{~b}$ \\
\hline SG + CD (1:1) & $25.18 \mathrm{ab}$ & $16.82 \mathrm{~b}$ \\
\hline SG + CD $(2: 1)$ & $31.89 \mathrm{ab}$ & $15.48 \mathrm{~b}$ \\
\hline SG $(100 \%)$ & $31.53 \mathrm{ab}$ & $16.01 \mathrm{~b}$ \\
\hline Control & $18.03 \mathrm{~b}$ & $14.25 \mathrm{~b}$ \\
\hline
\end{tabular}

Legend: SG: Brewery spent grain, CD: cow dung, PD: poultry droppings

Means in the same column with the same letters are not significantly different from each other at $5 \%$ level of probability

Table 3:-Effects of organic fertilizer on soil chemical properties after first planting

\begin{tabular}{|c|c|c|c|c|c|c|c|c|c|c|c|c|c|c|}
\hline $\begin{array}{l}\text { Treatme } \\
\text { nt }\end{array}$ & $\begin{array}{l}\text { pH } \\
\left(\mathbf{H}_{2}\right. \\
\mathbf{O})\end{array}$ & $\begin{array}{l}\text { OC } \\
\text { g/k } \\
\mathrm{g}\end{array}$ & $\begin{array}{l}\mathbf{N} \\
(\mathrm{g} / \mathrm{k} \\
\mathrm{g})\end{array}$ & $\begin{array}{l}\text { Avail. } \\
\text { P } \\
\text { (mg/k } \\
\text { g) }\end{array}$ & $\mathbf{K}$ & $\mathrm{Na}$ & $\begin{array}{l}\mathrm{Ca} \\
\mathrm{cmol} / \mathrm{k} \\
\mathrm{g}\end{array}$ & Mg & $\begin{array}{l}\text { Exch. } \\
\text { Acidit } \\
\text { y }\end{array}$ & $\begin{array}{l}\mathrm{CE} \\
\mathrm{C}\end{array}$ & Mn & $\begin{array}{l}\mathrm{Fe} \\
\mathrm{mg} / \mathrm{k} \\
\mathrm{g}\end{array}$ & $\mathbf{C u}$ & Zn \\
\hline $\begin{array}{l}\mathrm{SG}+\mathrm{PD} \\
(1: 1)\end{array}$ & 6.7 & $\begin{array}{l}31 . \\
0\end{array}$ & 2.98 & 45.70 & $\begin{array}{l}02 \\
7\end{array}$ & $\begin{array}{l}0.1 \\
5\end{array}$ & 5.27 & $\begin{array}{l}0.7 \\
1\end{array}$ & 0.20 & 6.60 & 16. & 377 & $\begin{array}{l}3.4 \\
3\end{array}$ & 1.2 \\
\hline $\begin{array}{l}\mathrm{SG}+\mathrm{PD} \\
(2: 1)\end{array}$ & 6.7 & $\begin{array}{l}30 . \\
4\end{array}$ & 2.80 & 57.61 & $\begin{array}{l}0.2 \\
6\end{array}$ & $\begin{array}{l}0.1 \\
5\end{array}$ & 3.76 & $\begin{array}{l}0.5 \\
3 \\
\end{array}$ & 0.80 & 5.49 & $\begin{array}{l}16 . \\
6\end{array}$ & 274 & $\begin{array}{l}4.3 \\
3 \\
\end{array}$ & $\begin{array}{l}1.0 \\
9\end{array}$ \\
\hline $\begin{array}{l}\mathrm{SG}+\mathrm{CD} \\
(1: 1)\end{array}$ & 6.8 & $\begin{array}{l}26 . \\
1\end{array}$ & 2.52 & 49.39 & $\begin{array}{l}0.2 \\
5\end{array}$ & $\begin{array}{l}0.1 \\
2\end{array}$ & 3.52 & $\begin{array}{l}0.6 \\
8\end{array}$ & 0.75 & 5.32 & $\begin{array}{l}15 . \\
3\end{array}$ & 285 & $\begin{array}{l}4.0 \\
9\end{array}$ & $\begin{array}{l}1.3 \\
3\end{array}$ \\
\hline $\begin{array}{l}\mathrm{SG}+\mathrm{CD} \\
(2: 1)\end{array}$ & 6.7 & $\begin{array}{l}29 . \\
0\end{array}$ & 2.73 & 39.62 & $\begin{array}{l}0.2 \\
4\end{array}$ & $\begin{array}{l}0.1 \\
2\end{array}$ & 3.34 & $\begin{array}{l}0.8 \\
3\end{array}$ & 0.40 & 4.93 & $\begin{array}{l}10 . \\
6\end{array}$ & 315 & $\begin{array}{l}4.1 \\
0\end{array}$ & $\begin{array}{l}1.6 \\
1\end{array}$ \\
\hline SG & 6.7 & 28. & 2.70 & 46.25 & 0.2 & 0.1 & 2.88 & 0.6 & 0.30 & 4.14 & 11. & 305 & 5.4 & 2.2 \\
\hline
\end{tabular}




\begin{tabular}{|l|l|l|l|l|l|l|l|l|l|l|l|l|l|l|}
\hline$(100 \%)$ & & 4 & & & 3 & 1 & & 2 & & & 9 & & 5 & 1 \\
\hline Control & 6.5 & 20. & 2.41 & 25.39 & 0.1 & 0.1 & 1.74 & 0.3 & 1.15 & 3.45 & 18. & 238 & 6.9 & 1.8 \\
1 & & & & 1 & 1 & & 4 & & & 4 & & 7 \\
7
\end{tabular}

Legend: SG: Brewery spent grain, CD: cow dung, PD: poultry droppings, OC: organic carbon CEC: cation exchange capacity, SD: standard deviation

Table 4:-Effects of organic fertilizer on soil chemical properties after residual planting

\begin{tabular}{|c|c|c|c|c|c|c|c|c|c|c|c|c|c|c|}
\hline $\begin{array}{l}\text { Treatme } \\
\text { nt }\end{array}$ & $\begin{array}{l}\text { pH } \\
\left(\mathbf{H}_{2}\right. \\
\mathbf{O})\end{array}$ & $\begin{array}{l}\text { O. } \\
\text { C } \\
\text { g/k } \\
\text { g }\end{array}$ & $\begin{array}{l}\mathbf{N} \\
(\mathrm{g} / \mathrm{k} \\
\mathrm{g})\end{array}$ & $\begin{array}{l}\text { Avail } \\
\text { P } \\
(\mathbf{m g} / \mathbf{k} \\
\text { g) }\end{array}$ & $\mathbf{K}$ & $\mathrm{Na}$ & $\begin{array}{l}\mathrm{Ca} \\
\mathrm{cmol} / \mathrm{k} \\
\mathrm{g}\end{array}$ & Mg & $\begin{array}{l}\text { Exch } \\
\text { Acidit } \\
\mathbf{y}\end{array}$ & $\begin{array}{l}\mathbf{C E} \\
\mathrm{C}\end{array}$ & $\begin{array}{l}\mathbf{M} \\
\mathbf{n}\end{array}$ & $\mathbf{F e}$ & $\begin{array}{l}\mathrm{Cu} \\
\mathrm{mg} / \mathrm{k} \\
\mathrm{g}\end{array}$ & $\mathbf{Z n}$ \\
\hline $\begin{array}{l}\text { SG + PD } \\
(1: 1)\end{array}$ & 6.5 & $\begin{array}{l}33 . \\
0\end{array}$ & 2.91 & 40.39 & $\begin{array}{l}0.2 \\
1\end{array}$ & $\begin{array}{l}0.1 \\
5\end{array}$ & 2.77 & $\begin{array}{l}0.6 \\
8\end{array}$ & 0.35 & 4.16 & 9.4 & $\begin{array}{l}245 . \\
0\end{array}$ & 4.65 & $\begin{array}{l}1.7 \\
3\end{array}$ \\
\hline $\begin{array}{l}\text { SG + PD } \\
(2: 1)\end{array}$ & 6.5 & $\begin{array}{l}29 . \\
4\end{array}$ & 2.79 & 45.27 & $\begin{array}{l}0.1 \\
7\end{array}$ & $\begin{array}{l}0.1 \\
5\end{array}$ & 2.44 & $\begin{array}{l}0.6 \\
4\end{array}$ & 0.85 & 4.25 & $\begin{array}{l}14 . \\
5\end{array}$ & $\begin{array}{l}272 . \\
0\end{array}$ & 6.43 & $\begin{array}{l}2.1 \\
5\end{array}$ \\
\hline $\begin{array}{l}\mathrm{SG}+\mathrm{CD} \\
(1: 1)\end{array}$ & 6.5 & $\begin{array}{l}24 . \\
1\end{array}$ & 2.47 & 36.02 & $\begin{array}{l}0.2 \\
0\end{array}$ & $\begin{array}{l}0.1 \\
2\end{array}$ & 2.00 & $\begin{array}{l}0.7 \\
1\end{array}$ & 0.35 & 3.38 & $\begin{array}{l}12 . \\
7\end{array}$ & $\begin{array}{l}240 . \\
0\end{array}$ & 5.10 & $\begin{array}{l}1.9 \\
3\end{array}$ \\
\hline $\begin{array}{l}\mathrm{SG}+\mathrm{CD} \\
(2: 1)\end{array}$ & 6.5 & $\begin{array}{l}27 . \\
4\end{array}$ & 2.53 & 35.97 & $\begin{array}{l}0.1 \\
3\end{array}$ & $\begin{array}{l}0.1 \\
1\end{array}$ & 2.36 & $\begin{array}{l}0.8 \\
6 \\
\end{array}$ & 0.45 & 3.91 & $\begin{array}{l}12 . \\
4\end{array}$ & $\begin{array}{l}272 . \\
0\end{array}$ & 8.41 & $\begin{array}{l}2.0 \\
4\end{array}$ \\
\hline $\begin{array}{l}\text { SG } \\
(100 \%)\end{array}$ & 6.4 & $\begin{array}{l}27 . \\
4\end{array}$ & 2.50 & 33.58 & $\begin{array}{l}0.1 \\
0 \\
\end{array}$ & $\begin{array}{l}0.1 \\
0 \\
\end{array}$ & 1.81 & $\begin{array}{l}0.5 \\
8 \\
\end{array}$ & 0.55 & 3.14 & $\begin{array}{l}10 . \\
9\end{array}$ & $\begin{array}{l}245 . \\
0\end{array}$ & 1.59 & $\begin{array}{l}1.6 \\
3 \\
\end{array}$ \\
\hline Control & 6.3 & $\begin{array}{l}19 . \\
7\end{array}$ & 2.36 & 24.75 & $\begin{array}{l}0.0 \\
9\end{array}$ & $\begin{array}{l}0.1 \\
1\end{array}$ & 1.02 & $\begin{array}{l}0.4 \\
3 \\
\end{array}$ & 1.05 & 2.70 & $\begin{array}{l}12 . \\
1\end{array}$ & $\begin{array}{l}265 . \\
0\end{array}$ & 4.46 & $\begin{array}{l}1.7 \\
0\end{array}$ \\
\hline Means & 6.5 & $\begin{array}{l}26 . \\
5\end{array}$ & 2.59 & 36.00 & $\begin{array}{l}0.1 \\
5 \\
\end{array}$ & $\begin{array}{l}0.1 \\
2 \\
\end{array}$ & 2.07 & $\begin{array}{l}0.6 \\
5 \\
\end{array}$ & 0.6 & 3.59 & $\begin{array}{l}12 . \\
0\end{array}$ & $\begin{array}{l}256 . \\
5\end{array}$ & 5.11 & $\begin{array}{l}1.8 \\
6\end{array}$ \\
\hline SD & 0.08 & $\begin{array}{l}4.0 \\
6\end{array}$ & 0.21 & 6.89 & $\begin{array}{l}0.0 \\
5\end{array}$ & $\begin{array}{l}0.0 \\
2 \\
\end{array}$ & 0.61 & $\begin{array}{l}0.1 \\
4\end{array}$ & 0.29 & 0.62 & $\begin{array}{l}1.7 \\
3\end{array}$ & $\begin{array}{l}14.7 \\
6\end{array}$ & 2.27 & $\begin{array}{l}0.2 \\
1 \\
\end{array}$ \\
\hline
\end{tabular}

Legend: SG: Brewery spent grain, CD: cow dung, PD: poultry droppings, OC: organic carbon, CEC: cation exchange capacity, SD: standard deviation

\section{Discussion:-}

The use of brewery spent grains as compost manure in this study for crop production is a score in agricultural development and environmental sanitation as this will reduce the level of the waste dump on the streets which causes air pollution and other environmental hazards. Brewery spent grains are daily produced in large quantities by the beer producing breweries. Part of it is used for animal feed and the remnant dumped at the brewery sites or some dump hills. The results of this study have shown that the composted spent grains can richly improve the soil nutrient status for maximum crop yield.

\section{Effect of the composts on soil nutrient status}

The spent grains plus poultry droppings performed better than the spent grains plus cow dung in the release of organic matter, $\mathrm{P}, \mathrm{N}, \mathrm{K}, \mathrm{Na}$ and $\mathrm{Ca}$ into the soil after the first and residual planting. All these are suggestive of high nutrient composition of poultry droppings as obtained in this study. All the treatments reduced the exchangeable acidity when compared with the control. This reduction of soil exchangeable acidity following application of compost can be attributed to the release of organic acids (during mineralization of manure), which in turn may have suppressed $\mathrm{Al}$ content in the soil through chelation (Onwonga et al., 2008; Okwuagwu et al., 2003). Increased Mg availability in the soil as a result of compost application could be due to the release of the nutrient through manure decomposition (Adeleye et al., 2010). This is also similar to the report of Rahman et al. (2002) who found increased available $\mathrm{Mg}$ in the soil as a result of applied manure and attributed the increase to improved soil $\mathrm{pH}$ and reduced exchangeable acidity. The increase in phosphorus and potassium by the application of composts can be as a result of 
mineralization of the composts with released nutrient (Shen and Shen, 2001). Similar findings were reported by Chimdi et al. (2012). The application of compost was observed to increase the organic matter due to the high amount of organic matter present in the compost materials (brewery spent grain). The result also showed that the application of manure had significant effect on the Nitrogen content of the soil.This may be due to supply of $\mathrm{N}$ in the compost through mineralization associated with improved soil condition for microbial activities as a result of increased organic matter. Mba and Mbagwu (2003), however, pointed out the differences in the abilities of organic wastes to provide nutrients and enhance soil qualities due to differences in their rates of decomposition and nutrient release patterns.

\section{Conclusion:-}

To improve the fertility status of the soil over a long term, there is a need to use organic fertilizers such as compost. Brewery waste which has been utilised for agricultural purposes should be utilised in composting with animal wastes like poultry manure and cow dung to improve soil nutrients. The study aimed at determining the effects of brewery waste-based compost on some physical and chemical properties of the soil.

In conclusion, the brewery waste-based compost contributed to the organic matter, nitrogen and phosphorus content of the soil, reduced the exchangeable acidity and also increased the exchangeable bases in the soil. The treatments (compost) did not significantly affect the texture of the soil.The treatments had significant effect on the Cation Exchange Capacity of the soil. Spent grain plus poultry manure (1:1) gave the best result. In conclusion, the use of brewery waste-based composts for soil amendment added value to the improvement of the soil nutrient status.

\section{References:-}

1. Adeleye E. O., Ayeni L. S. and Ojeniyi S. O. (2010). Effect of Poultry Manure on Soil Physico-Chemical Properties, Leaf Nutrient Contents and Yield of Yam (Dioscorea rotundata) on Alfisol in South western Nigeria. J. Am. Sc., 6(10): $871-878$.

2. Agegnehu G, vanBeek C and Bird M (2014). Influence of integrated soil fertility management in wheat and tef productivity and soil chemical properties in the highland tropical environment. Journal of Soil Science and Plant Nutrition, 2014, 14

3. Amlinger F, Peyr S, Geszti J, Dreher P, Karlheinz W. and Nortcliff S. (2007). Beneficial effects of compost application on fertility and productivity of soils. Literature Study, Federal Ministry for Agriculture and Forestry, Envi. and Water Management, Austria. Available: www.umweltnet.at/filemanager/download/20558/ (Dec. 2013)

4. AOAC (2005). Official method of Analysis $17^{\text {th }}$ Edition. Association of Analytical Chemists, Washington D.C.

5. Azagaku, E. D. and H. Anzaku. (2002). Effect of NPK Fertilizer Levels on the Growth and Development of early Maturing Maize Cultivar (TZESR -W). In M. Iloeje, G. Osuji, Udoh H. and G. Asumugha (eds). Agriculture: A Basis for Poverty Eradication and Conflict Resolution. Proceedings of the 36th Annual Conference of the Agricultural Society of Nigeria Held at the Federal University of Technology Owerri, Nigeria, 20- 24 October 2002, PP.106-111.

6. Bouyoucos, G. J. (1962). Hydrometer method for making particle size analysis of soils. Soil Science Society of America Proceedings, 26, 464-465.

7. Bremner, J. M., and Mulvaney, C. S. (1982). Nitrogen. In A. I. Page, R. H. Miller, \& D. R. Keeney(Eds.). The method of soil analysis, part 2, Agron. Monogr. 9, $2^{\text {nd }}$ ed. (pp. 159- 165). Madison: ASA.

8. Brown S and Cotton M (2011). Changes in Soil Properties and Carbon Content Following Compost BMLFUW, European Commission, Vienna and Brussels Application: Results of On-farm Sampling. Compost Science and Utilization, (2011), Vol. 19, No. 1, 88-97.

9. Chimdi A, Gebrekidan V, Kibret K, Tadesse A (2012). Effects of Liming on Acidity-Related Chemical Properties of Soils of Different Land Use Systems in Western Oromia, Ethiopia. World J. Agric. Sci., 8(6): 560-567.

10. FAO (2001). Soil Fertility Management in Support of Food security in Sub-Saharan Africa. Available on http://ftp.fao.org/agl/agll/docs/foodsec.pdf

11. Getinet A. (2016). A review on impact of compost on soil properties, water use and crop productivity. Article in Agricultural Science Research Journal. Vol. 4(3), pp. 93-104, $\quad$ March $2016 . \quad$ DOI: 10.14662/ARJASR2016.010

12. Maki, H., Sasaki, T. and Haramaya S. (2005). Phytooxidation of biodegradable crude oil and toxicity of the phytooxidized products. Chemosphere, vol. 44, pp. 1145-1151, 2005. 
13. Mba, C. N. and Mbagwu J. S. C. (2003). Studies on decomposition, mineralogical rate and biochemical oxygen demand of organic wastes. International Journal of Agriculture and $\quad$ Biological Services 2: 5154.

14. Mohammad H. G., Denney M. J. and Iyekar C. (2004). Use of Composted Organic Wastes as Alternative to Synthetic Fertilizers for Enhancing Crop Productivity and Agricultural Sustainability on the Tropical Island of Guam. 13th International Soil Conservation Organization Conference - Brisbane, July 2004.

15. Ndubuaku, U. M. and Lucas E. O. (2000). Nutrient release and fertilizer need of soils of old cocoa plots. Nigerian journal of science, vol. 34, No. 4: 381-387Pp.

16. Nelson, D. W. and Sommers, L. S. (1982). Total carbon. A. L. Page, R. H. Miller, \& D.R. Keeney (Eds.), Method of soil analysis, part 2, Agronomy Monograph No. 9, $2^{\text {nd }}$ ed. (pp. $\quad$ 539-579). Madison: ASA.

17. Okwuagwu M. I., Alleh M. E. and Osemwota I. O. (2003). The effects of organic and inorganic manure on soil properties and yield of okra in Nigeria. Afric. Crop Sci. Confer. Proc., 6: 390-393.

18. Onwonga R. N., Lelei J. J., Freyer B., Friedel J. K., Mwonga S. M. and Wandhawa P. (2008). Low cost technologies for enhance $\mathrm{N}$ and $\mathrm{P}$ availability and maize (Zea mays L.) performance on acid soils. World J. Agric. Sci., 4(5): 862-873.

19. Paradelo R., Villada A. and Barral M. T. (2011). Reduction of the short term availability of copper, lead and zinc in a contaminated soil amended with municipal solid waste compost. Journal of Hazardous Materials, 188 (1-3), 98-104

20. Paul M. (2003). Long-term effects of manure compost and mineral fertilizers on soil biological activity as related to soil structure and crop yield. In: Amlinger F, Nortcliff S, Weinfurtner K, Dreher P, 2003c. Applying Compost - Benefits and Needs, Proc. of a seminar 22 - 23 November 2001,

21. Rahman M. A., Meisner C. A., Duxbury J. M., Lauren J. and Hossain A. B. S. (2002). Yield response and change in soil nutrient availability by application of lime, fertilizer and micronutrients in an acidic soil in a rice-wheat cropping system. Paper presented in 17th WCSS, 14th-21st August 2002. Thailand. Pp 176 (415p).

22. Seran T. H. Srikrishnah S and Ahamed M. M. Z. (2010). Effect of different levels of inorganic fertilizers and compost as basal application on the growth and yield of onion (Allium $\quad$ cepa $\quad$ L.). The Journal of Agricultural Sciences, 2010, vol. 5, no 2: 64-70.

23. Shen Q. R. and Shen Z. G. (2001). Effects of pig manure and wheat straw on growth of mung bean seedlings grown in aluminium toxicity soil. Biores. Tech., 76: 235-240. 